\title{
A DIVERSITY OF OPINIONS ON THE STANDARDS OF INTERNATIONAL CUSTOMS LAW
}

A number of multilateral international customs agreements, bilateral treaties of Ukraine, acts of the World Customs Organization, instruments of the European Union, legal acts of Ukraine and scientific literature require careful examination of their structure and content. The authors have studied the standards of international customs law based on the following theory: standards are an independent category of international customs law and differ from its principles and legal norms; standards of international customs law serve as a subsidiary element in legal regulation of customs relations, because in contrast to the principles and norms of international customs law, they are not intended to regulate customs relations independently; standards of international customs law derive from its principles and legal norms.

The concept of "standards of international customs law" is proposed to define technical specifications, templates, samples, models, methodical recommendations for the certain type of activity or achievement of anticipated results. The standards are elaborated in order to promote the realization of principles and norms of international customs law, which implementation into practice of customs administrations is carried out by subjects of international customs law taking into account individual needs and opportunities, on the terms and in accordance with the procedure defined by international legal acts.

Alternatively, from the perspective of the standards of international customs law, an analysis of the Customs Code of Ukraine was carried out and some recommendations for its improvement were proposed. proposed. The research findings carried out within this article may contribute to the implementation of the principles, norms and standards of international customs law by Ukraine, and may be used to amend the Customs Code of Ukraine in power.

Key words: international customs law, standards, principles, legal norms, international treaties, Customs Code of Ukraine.

JEL Classification: K33.

\section{Serhiy PEREPOLKIN,}

Dnipropetrovsk State University of Internal Affairs, Ukraine

psm-13@ukr.net

\section{Tetiana SYROID,}

V.N. Karazin Kharkiv National

University, Ukraine

syroid02@gmail.com

\section{Introduction}

Joint activity of states aimed at overcoming existing and preventing new global problems (threats of civilization's self-destruction as a result of a possible nuclear conflict, overcoming economic underdevelopment in the world, ensuring sustainability, developing information and trade exchange, destabilization of international relations and increasing terrorism, etc.), has positive effects in various fields of interstate relations, including the field of international customs law, namely, it changes the concept of absolute customs' sovereignty of states; promotes more intensive international customs cooperation; accelerates the processes of convergence of customs systems of different states, etc. 
Achievement of the goals by states, both abovementioned and in other areas of their joint activity in sphere of international customs law, depends on many factors, among which one of the most important is adoption and implementation of various international standards in this area, is precisely coordinated and significant understanding of such standards.

The mentioned issue is relevant for Ukraine, customs affairs of which have been in a state of constant reform since the declaration of independence by our state. Thus, according to Art. 7(2) of the Customs Code of Ukraine: "The state customs affairs are carried out in compliance with internationally accepted forms of entry of goods, methods for determining the customs value of goods, systems for classifying and coding goods and customs statistics, and other generally recognized norms and standards". The gradual approximation of Ukrainian legislation in customs sphere to the customs legislation of the European Union (hereinafter - EU), as defined in EU standards and international standards, is indicated in Art. 84 of Association Agreements between Ukraine, on the one hand, and the EU, the European Atomic Energy Community and their Member States, on the other side of June 27, 2014 (hereinafter - Association Agreement or Agreement). In addition, in accordance with Art. 76(1) the parties to the Agreement have also agreed to ensure the application of a set of international customs documents created by the World Customs Organization used in customs affairs and trade, the list of which begins with the Framework Standards for Security and Facilitation of International Trade Procedures, 2005 etc.

At the same time, despite the fact that the category "standard" is widely used in legal acts of Ukrainian legislation regarding issues of the state customs affairs, particularly in international customs treaties of Ukraine, for the last three decades it has consistently been associated by customs officials with the priority directions of improvement of law enforcement activity in the sphere of state customs affairs of Ukraine and for a long time is discussed by domestic scientists; there are no clear answers to questions "What are the standards of international customs law?" and "What position should be assumed for their correct understanding?" neither on doctrinal nor official levels.

Therefore, the purpose of this article is to establish peculiarities of understanding the standards of international customs law by scientists from Ukraine and foreign states, develop a universal concept of customs affairs for the domestic theorists and practitioners in this sphere and propose to improve Ukrainian legislation on the issues of customs affairs for more effective implementation of the standards of international customs law.

Achieving that goal requires careful examination of a structure and content of a number of multilateral international customs agreements (in particular, the International Convention on the Simplification and Harmonization of Customs Procedures of 18 May, 1973), bilateral treaties of Ukraine (in particular, the Association Agreement between Ukraine, on the one hand, and the European Union, the European Atomic Energy Community and their Member States, on the other hand, of 27 June, 2014), acts of World Customs Organization (in particular, Resolutions on the Framework Standards for Security and Facilitation of International Trade Procedures), European Union instruments (in particular, "Customs Blueprints"), legal acts of Ukrainian legislation (in particular, Customs Code of Ukraine), encyclopedias, scientific and educational literature.

\section{Literature review}

Many researchers have considered the issues of theory and implementation of international customs law's standards in their publications, thus the analysis of existing developments in the sphere of scientific research indicates the diversity of views upon their understanding. The gen- 
eralization of published scientific papers allows us to combine the existing diversity of views in understanding the standards of international customs law within the framework of two approaches: scientific and practical.

For the Ukrainian legal doctrine, as well as for the doctrine of most post-Soviet states, a scientific approach is more common. Within its framework published papers have a primarily descriptive, highly specialized academic character. In their content, there is usually no scientific discussion as well as practical indicators of the implementation of international customs law standards, because the authors focus on highlighting their own vision of issue under study, which is not always well-founded and in some cases is internally contradictory. As a result, the doctrine of international customs law has given rise to an uncertain terminological situation in which there is the use of different terms for verbal labelling of the concept of "standards" ("international standards") enshrined at national and international levels; there is no unity in the views on the delimitation of the terms "standards", "principles" and "norms" of international customs law, ambiguity is the vision of their legal force, etc. In addition, this situation has a negative effect on law-making and enforcement activity in the sphere of customs affairs, as the existing national pluralism of approaches to understanding the standards of international customs law (within which it is not clear whether the same meaning employs scientists and legislators in the concept that constitutes the subject of our consideration) is also reproduced in the acts of the legislation of Ukraine on the issues of state customs, which often leads to various misunderstandings when implementing the standards of international customs law both at domestic and international levels of legal regulation of customs relations.

In general, various representatives of Ukrainian legal doctrine pointed out the fact of the existence of international customs law standards, their significant influence on customs policy, customs legislation and customs affairs of Ukraine, and the need for scientific reflection, but no further studies have been carried out yet. Among such authors should be mentioned the following: Mytsyk, 1994; Sandrovskij, 2001; Perepadia, 2007; Filatov 2013; Muzyka, 2015 and others.

Other scholars focused on general description of the structure and content of international legal acts, through which certain international standards were approved, and made theoretical proposals on their implementation at the domestic level, among them: Dodin, 2005; Skomarovskyi, 2005; Havriushenko, 2006; Pryimachenko, 2007; Berezhnik, 2009; Pashko, 2009; Klian, 2011; Chorna, 2013; Shulha, 2014; Denysenko, 2015; Kalinichenko, 2015; Sai, 2016; Kveliashvili, 2016; Dorofeieva, 2017 and others. In the works published under their authorship, it was mainly about the Framework Standards for Security and Facilitation of International Trade in 2005 and the International Convention on the Simplification and Harmonization of Customs Procedures of 18 May, 1973.

Less attention was paid to studying the European Union's customs law standards by Ukrainian scientists, that was manifested in a small number of scientific works compared with the results of the work of previous group of researchers. Kivalov, 2001, Mazur, 2005, Filatov, 2008, Romanenko, 2010, Kistanova, 2014, Bykov, 2017, Kormych, 2017 and others devoted their works to the topic mentioned.

On the contrary, in the writings of the representatives of applied approach the theory of standards of international customs law and the implementation of international legal acts used for their approval is almost neglected, since in their content the authors focus on the analysis of indicators achieved by the results of implementation of international standards by national customs authorities, as well on the development of proposals for further improvement of both their 
content and implementation practices. They recognize the importance of international customs law standards for the development of international trade and the implementation of various types of commercial and non-commercial activities, but do not give their exact definition (the "only accurate universal definition"). Thus, what exactly the representatives of this approach refer to the notion "standards of international customs law" often remains uncertain and obvious only to them. The range of their scientific interests is broader than that of domestic scientists, and includes, in addition to the standards of the International Convention on the Simplification and Harmonization of Customs Procedures of May 18, 1973, and the Resolutions of the Customs Cooperation Council on the Framework Standards for Security and Facilitation of International Trade 2005, other standards developed by the results of the activities of the World Customs Organization, the World Trade Organization, the European Union and other intergovernmental organizations. The most prominent representatives of this approach are the following scientists: Hein, Rydsijk, 2006; Matsudaira, 2007; Gordhan, 2007; Lux, 2007; Hossain, 2008; Rovetta, 2008; Ireland, 2009; Weerth, 2009; Kafeero, 2009; Cheng, 2010; Wolffgang and Dallimore, 2012; Lyons, 2018 and others.

\section{Research methodology}

In the doctrine of international customs law, there is no unity in the approach to understanding the concept of "standards of international customs law". That is due not only to the subjective factor but also to the fact that the terms "standard" and "international standard" in legal encyclopedic literature, legal doctrine and Ukrainian legislation on the issues of state customs are characterized as polysemic.

The Dictionary of foreign languages edited by Pustovit (2000) contains the following interpretation of the word "standard" - a sample, a pattern, a model that becomes a benchmark for other objects.

According to the Dictionary of modern concepts and terms edited by Makarenko (2002) the term "standard" is interpreted as a [typical] sample, pattern, [normative] model taken for the original to be compared with other objects, and the term "international" means connected with relations between states, which is relevant to foreign policy.

In legal encyclopedia edited by Shemshuchenko (2003) the term "standard" (from the English Standard - norm, sample, model) is proposed to be understood as a specific document, which specifies certain list of rules of general and multiple use, universal principles and / or characteristics of a particular activity or its results, the purpose of which is to achieve the optimum level of harmonization of a particular branch. At the same time, the term "international standards" has the following meanings: 1) international legal norms and principles that provide the standards of conduct for subjects of international law in certain spheres of interstate cooperation. Standards set certain minimum requirements that all states must adhere to. They are contained in international treaties and other sources of international law; 2) documents of the International Organization for Standardization (ISO), which establish rules and requirements in the sphere of finished products of mass production, semi-finished products and raw materials.

Many scholars formulate author's definitions of the term "international standard" based on the principles set forth in Art. 1. of Standardization Act of Ukraine of 5 June, 2014 defining the term "standard", namely: "the standard is a normative document based on consensus, adopted by a recognized body, which establishes for a general and repeated use of a rule, instruction or characteristic of activity or its results, and is aimed at achieving the optimum degree of harmonization in a particular area". 
As a result, representatives of the legal doctrine often identify international standards with norms of law or with normative documents use the notion of "standard in law" to interpret domestic standards defined by the national legal system, and for international standards - the notion of "legal standard", and they suggest to consider international standards as a new type of sources of international law, etc.

For instance, professor Baimuratov (2006) believes that international standards are certain international law norms that are stipulated by international treaties and developed by States within the framework of international intergovernmental organizations (IGO).

Moroz \& Kravchuk (2017) believe that the distinction between the concepts of "legal standard" and "standard in law", and hence domestic and international standards, is due to different approaches to understanding the law. In their view, the notion of "standard in law", developed on the basis of the positivist concept, should be interpreted as the normative-defined limits of admissible behaviour aimed at achieving the optimum degree of harmonization in a certain sphere. Basically, legislative consolidation of the standard as a normative document means formal expression of "standard in law". The notion of "legal standard" is a wider concept that, besides the regulatory boundaries of admissible behaviour, also takes into account general principles of justice and reflects the natural-legal concept of legal consciousness.

Professor Kyivets (2012) speaks on the possibility of considering the category of "legal standard" in the sense of not only individual rules, but as a document that establishes a set of rules, regulations, requirements for standardization facility, which sets object's characteristics aimed at voluntary multiuse. Kyivets (2010) also believes that in the near future may take place of a new major source of international law - the standard, examples of which have long taken within its competence by various international organizations, including the World Health Organization (WHO), World Meteorological Organization (WMO), International Civil Aviation Organization (ICAO), etc.

The terms "standard" and "international standard" are ambiguously determined and are also used in the Ukrainian legislation on state customs affairs. For instance, provisions of Part 2, Art. 7 of the Customs Code of Ukraine contain, on the one hand, the identification of accepted international practice forms ..., methods ... and systems ... (see above) both as norms and standards. On the other hand, the legislator used the approach to the definition of standards, in accordance with which the state customs affairs should be carried out in Ukraine, according to which such standards can be considered as direct international standards of customs affairs, as well as standards of other related to customs affairs of state regulation, the only defining requirement of belonging to which is their universal recognition.

Another act of Ukrainian legislation on issues of state customs affairs - the Ordinance of the Cabinet of Ministers of Ukraine "on approval of the Concept of involvement of companies (advisers) to reform the customs of the State Fiscal Service" of 11 February, 2016, No.267-p (hereinafter - the Concept), did not mention universally recognized in the world norms and standards, because within the framework of the problem addressed by the Concept, main attention is focused on the elimination of differences between customs standards of Ukraine and EU standards. At the same time, it should be emphasized that the category "customs standards of Ukraine" is not used in Ukrainian legislation on issues of state customs, in particular in the Association Agreement. The situation with regard to the category of "EU standards" is uncertain as, in accordance with the objective of the Concept, the reform of customs of State Fiscal Service (hereinafter - SFS) should be based on the "EU Customs Prototypes" - a guideline in the 
customs cooperation between Ukraine and the EU, which, as noted by Chentsov (2015), is the standard proposed by the European Commission for the customs administrations of countries that are candidates for accession to the EU. However, on the single web-portal of the executive authorities of Ukraine the "EU Customs Prototypes" indicated in the Concept are mentioned as an international document used in the development of the Concept called "EU Customs Standards" (Customs Blueprints), and on the website of SFS of Ukraine - as the customs standards of the EU Customs Blueprints.

It should be noted that the original English version of "Customs Blueprints", as well as their translation into French ("Schemas directeurs relatifs aux douanes") and Russian ("Свод таможенных стандартов") languages, are available on the official website of the European Commission. However, from the standpoint of Kormych (2017), the shady Russian translation of the "Свод таможенных стандартов" and its Ukrainian "Зведені митні стандарти" are incorrect translations of "Customs Blueprints". After all, any English glossary notes that "blueprints" is a plan (a scheme) or a document that serves as a plan function. This is confirmed by the translation from French "Schemas directeurs relatifs aux douanes", that is, the customs master-plan. However, when international standards specify custom standards, the name is appropriate (for example, SAFE Framework of Standards to secure and facilitate global trade). Incorrect translation of the title causes misunderstandings about how the Customs Blueprints are used. Therefore, Customs Blueprints is not standards in the usual sense, because it is a certain technique and sequence of actions, as concluded by the scientist.

We share the opinion of Kormych (2017) about the inappropriateness of use of "Blueprints" of any of the abovementioned definitions, except the official term, that is, "Customs Blueprints", because the consequence of this, above all, may not be proper understanding of their essence, which leads to further different misunderstandings, in particular about the way of using blueprints. For the confirmation of our own position, we give the following arguments.

In an introductory part to "Blueprints" it is indicated that they should be considered as practical guidance, based on the best practices of the EU. Their development and improvement was caused by the need to assist non-EU countries in bringing their customs administrations in line with EU legislation and standards. Customs Blueprints are not part of either customs or tax legislation of the EU and therefore are not legally valid. Being a technical publication, they represent a valuable standard for the customs administration, the use of which is aimed at assessing the effectiveness of the work carried out and organizing its own path to better customs.

Consequently, the titles "EU Customs Prototypes" and "EU Customs Blueprints" are also unreasonably used by Ukrainian scientists and practitioners to refer to "Customs Blueprints", an instrument, the use of which is recommended by the EU to Ukraine for the gradual approximation of its customs legislation to the EU customs legislation and standards. The elimination of similar misunderstandings related to incorrect translation of the title and content of international legal acts of both universal and regional nature will facilitate the implementation of the official authentic translation of primary sources on the basis of which the Ukrainian state authorities are planning to reform the customs of SFS, that we, Perepolkin (2007\&2009), have already been highlighted in other works.

The uncertain terminological situation emerged in legal doctrine and in relation to the notion of "standards of international customs law", where, along with the terms "standards" and "international standards" fixed at the legislative level, scientists commonly use the following phrases: universally recognized in the world customs relations standards; world customs standards; 
world standards for customs regulation; international customs standards; international standards of customs affairs; international standards in the sphere of customs; international standards of customs regulation; international standards of customs affairs regulation; international standards in the sphere of customs regulation; international standards in customs sphere; international legal standards in customs sphere; standards in the customs sphere; international standards in the sphere of customs simplification; international standards for simplification and harmonization of customs procedures, etc.

There is lack of consensus among scholars in approaches to understanding the proposed terminological constructs, which they interpret as principles of international customs law, or as norms and provisions of international treaties, or as international treaties (conventions and agreements), or as the main management tools of World Customs Organization, or as a type of common law-making activity of states, etc.

For instance, Denysenko (2015) states in this regard: "The international customs standard is a group of treaty principles that begin to operate between states when they undertake to comply with them. This gives reason to believe that among the principles of international customs law, the majority is precisely the standards of simplification and harmonization of customs procedures within the framework of international trade".

From the standpoint of Sandrovskij (2001), who followed the comprehension of standards in a broad, general-sociological sense, where international standards in the customs sphere are certain models, patterns of behaviour or measure of actors conduct (international communication) embodied, in particular, in general, international treaties on international customs law.

Shulha (2014) believes that international standards are the provisions of contracts (agreements) in the sphere of customs regulation, which are subject to special transformation in national legislation. However, in the conclusions of the scientific article, the above-mentioned opinion received the following statement: "Nowadays, the customs legislation in power has transformed the provisions of a number of international treaties (agreements) that act as international standards in the sphere of customs regulation".

Halipov (2011), a representative of the Russian school of international law, also advocates similar view, that proposes to understand the norms and provisions of international treaties (conventions, agreements) that are subject to implementation in the national customs legislation in accordance with international standards in the sphere of customs regulation. At the same time, the scientist argues that international customs standards in the sphere of customs regulation and the obligation to comply with them formally appear for the Russian Federation with its accession to the Kyoto Convention (International Convention on the Simplification and Harmonization of Customs Procedures of 18 May, 1973), which is the only source of international standards for the State. The Framework Safety and Trade Facilitation standards does not include standards for customs law-making and, as they only contain technical recommendations for the implementation of the standards of Kyoto Convention, in particular in the sphere of customs control (preliminary provision of information, application of risk management system, international customs cooperation, interaction with foreign economic operators).

The only international document requiring Ukraine to comply with its national customs legislation with international standards in the customs sphere, is the Kyoto Convention, as recognized by Chorna (2013). However, it is not easy to realize what the representative of the school of administrative law of Ukraine understands by international standards, because in order to explain the concept of "international customs standard", Chorna (2015) uses at the same time four 
definitions, namely: 1) ... is the only (harmonized) normative model that is used at the administration of foreign economic activity at the interstate and / or national levels of customs systems; 2) ... is a unified normative standard form, the consent for the introduction of which is provided by authorized subjects of international law for the implementation of a single regulation of the foreign economic activity at intergovernmental and/or national levels; 3 ) ... is one of the types of implementation of the total law-making activity of States, with the aim of coordinating their interests and achieving common goals in the regulation of customs issues, taking as a basis the generally accepted principles and norms of international customs law; 4) ... is a unified standard model, created in accordance with the agreement of subjects of international law in the regulation of customs relations at the interstate, national and/or departmental levels.

As for the relation of Framework standards with provisions of the Kyoto Convention, they, according to Chorna (2013), are also recommendations for the most effective realization by customs authorities of their functions within the existing customs law institutes. Therefore, these standards cannot be considered as samples (models), which are subject to rulemaking in the customs sphere.

According to professor Shulha (2014), it is not necessary for national customs regulations to set requirements for customs administrations and participants in foreign economic activities aimed at the effective and uniform implementation of customs legislation in order to accelerate customs transit and ensure the proper security of international trade (consisting in preliminary declaration, interaction between customs administrations and their cooperation with foreign economic operators), contained in the Framework Safety and Trade Facilitation Standards.

\section{Empirical results}

In our opinion, the viewpoint on the lack in World Customs Organization's Framework for Safety and Trade in World Trade, as of 23 June 2005, of standards for customs rule-making, as well as the statement that it is not possible to consider such standards as models (samples) subject to taking into account while rule-making in the customs sphere, is false. To confirm our own position, even without referring to the original source, we give the following two arguments. Firstly, the Framework Standards for Security and Facilitation of World Trade are mentioned in many international legal acts in the sphere of customs regulation, in particular in the Customs Blueprints, as an example of international standards, which States required to ensure the application of. Secondly, to ensure the application of the Framework Safety and Trade Facilitation 2005, as one of the international documents developed by the World Customs Organization, our state has undertaken in accordance with Clause (h) Part 1. Art. 76 of the Association Agreements.

We disagree with Chorna (2013) finding that the Kyoto Convention is the only international document that requires Ukraine to comply with its national customs legislation with international customs standards. Such an assertion does not correspond to that used by the legislator in the Customs Code of Ukraine for an expanded approach to the definition of generally accepted norms and standards in the world, in compliance with which the state customs affairs are carried out in Ukraine, and the Kyoto Convention, Standards 3.11 and 7.2 of which refer to the international standards, enshrined in other international legal acts, such as the Recommendations of the Council for Customs Cooperation in the sphere of Information Technology.

In our opinion, the approach to interpreting the term "standard" through the terms "principle" and "norm" is also a point to debate. After all, as principles and norms are not identical 
categories, Perepolkin (2017), and standards, in close relations with them, is an independent category of international customs law.

International customs law standards have an auxiliary role in implementing its principles and norms at the international and national levels of legal regulation of customs relations. With the help of standards, specific technical specifications, standard forms, models, samples, methodological recommendations are fixed, minimum requirements for the implementation of the principles and norms of international customs law, the wider implementation of which is considered desirable and is associated with the individual needs and capabilities of each separate customs administration.

The standards of international customs law appear after its principles and norms, or both at the same time. Accordingly, the emergence of new principles and norms of international customs law, their improvement or cancellation, can automatically affect the appearance, improvement or cancellation its standards as well. In other words, they are not once and for all established, unchanged.

Standards of international customs law differ from its principles and norms by legal force. Being predominantly technical recommendations, the standards of international customs law are not legally binding in advance. Their introduction into the practical activities of customs administrations is carried out by subjects of international customs law on a voluntary basis by implementing the positive actions stipulated in the standards. The customs administrations are given the right, in accordance with their interests, the needs and possibilities to decide on the standards themselves or not, to implement them in accordance with the procedure and in the scope of a high standard or to go beyond the minimum requirements established and to provide conditions more favorable than those provided by the standard, to accept decisions on the terms, stages and methods of their implementation. Therefore, for the non-use or improper use of their rights, the subjects of international customs law cannot be subject to legal liability.

The advisory character of most international customs law standards also follows from the nature and content of international legal instruments through which their adoption is carried out. For the most part, such acts are resolutions, recommendations, declarations of international intergovernmental organizations, such as the Customs Cooperation Council. Less commonly to this end, annexes to multilateral international treaties may be used, the expression of consent for binding on them is not a prerequisite for accession to the contract and is carried out voluntarily by a subject of international customs law. Certain exception to this rule is the Kyoto Convention, each of the contracting parties to the latter undertakes to facilitate the simplification and harmonization of customs procedures, observing, in accordance with the provisions of this Convention, standards, transitional standards and recommended practices (hereinafter - the Kyoto Conventions standards) contained in the annexes to this Convention. Therein Art. 13 of the Kyoto Convention provides that each contracting party: must adopt the standards adopted by it for the General Annex, the Special Annexes and their sections not later than 36 months from the date of entry into force of these Special Annexes and their sections for the indicated contracting party; implements its adopted transitional standards of the General Annex for a period of up to 60 months from the date of the effective date of the General Application for the indicated contracting party; implements its recommended practice of the Special Applications or their sections not later than 36 months from the date of entry into force of these Special Applications and their sections for the indicated contracting party, unless there were any reservations regarding one or more of these recommended practices. In response, according to Art. 12 of the Con- 
vention, any of its contracting parties, when signing, ratifying or acceding to it, undertakes the obligations specified in the provisions of the General Annex and specifies which of the Special Annexes or their sections if any, the Party accepts. Subsequently, such party has the right to notify the depositary of the acceptance of one or more of its Special Applications or their sections.

Consequently, the obligation of any contracting party under the Kyoto Convention to facilitate the simplification and harmonization of customs procedures is essentially in timely adherence to those standards set forth in the General Annex, as well as one or more Special Annexes or their sections, if such are accepted by the contracting party. It should be noted that observance (compliance) is only one of the forms of direct implementation of the requirements of the law, in which the subject of legal relationships does not commit acts prohibited by these prescriptions. According to such wording, the implementation of the requirements of the Kyoto Convention standards must be carried out by its contracting parties through passive conduct and only in terms of compliance with the legal prohibitions envisaged by them. At the same time, the implementation of a significant number of Kyoto Convention standards should be carried out through the fulfilment of positive actions stipulated by their requirements, that is, due to active behaviour. However, a non-specific and general description of such actions, as the actual and expected outcome of their implementation, even if the Kyoto Convention contracting parties are unilaterally prepared to implement its standards in the form of implementation, does not guarantee the reflection in their national legislation of identical terms and procedure of application of customs rules and procedures. Therefore, it can be argued that the mandatory nature of the Kyoto Convention standards differs from the obligations to implement standards adopted by acts of international intergovernmental organizations, the exact timing of implementation of the standards accepted by the contracting party and a clearly defined direct form of their implementation - compliance, in which the contracting party to the Convention is limited in the right to choose the use as a form of implementation of its standards, but not deprived of the right to realize their implementation in the form of execution, as well as go beyond the minimum requirements they set and provide conditions more favourable than those provided by such standards.

\section{Conclusions}

Summarizing the all above, we conclude that the study of the concept of "standards of international customs law" lies on the following theoretical positions:

1) Standards are an independent category of international customs law and differ from its principles and norms;

2) In legal regulation of customs relations, the standards of international customs law are given a subsidiary role, since, unlike the principles and norms of international customs law, they are not intended to implement the independent regulation of customs relations;

3) Standards of international customs law derive from its principles and norms. Their adoption is carried out in order to promote the implementation of the principles and norms of international customs law at national and international levels of legal regulation of customs relations;

4) Standards can be improved because they are not once and for all established, unchanged;

5) Standards are an integral part of the content of international customs law, and not merely one of its forms;

6) The majority of international customs law standards are not legally binding a priori. Their recommendation kind stems from the nature and content of international legal acts through which their adoption is carried out; 
7) The implementation of standards may be carried out on an individual, bilateral or multilateral basis. The basic direct form of their implementation is the use, and less observance and execution;

8) Standards of international customs law can be classified into different types and contain technical and legal requirements.

The concept of "standards of international customs law" can be defined as designed to promote the implementation of the principles and norms of international customs law technical specifications, templates, samples, patterns, models, methodical recommendations for a certain type of activity or achievement of the anticipated results, the implementation of which in the practical activity of customs administrations is carried out by subjects of international customs law taking into account individual needs and opportunities, on the terms and in accordance with the procedure determined by international legal acts.

Taking into account the above, we also propose to amend the content and structure of Art. 7 of the Customs Code of Ukraine, stating its Parts 1 and Part 2 as follows: "The procedure and conditions for the movement of goods through the customs border of Ukraine, their passage of customs control and customs clearance, introduction of mechanisms of tariff and non-tariff regulation of foreign economic activity, collection of customs payments, keeping statistics of customs cases, exchange of information on customs procedures, conduct of Ukrainian classification of goods of foreign economic activity, conduct in accordance with the law of state control of non-food products during its introduction into the customs territory of Ukraine, assistance in preventing and counteracting smuggling, combating the violations of customs rules, establishing and ensuring the proper functioning of the revenue and expenditure authorities and other measures aimed at implementing state policy within the framework of state customs affairs, constitute a state customs transaction which is carried out with observance, execution and using internationally recognized principles, norms and standards of international law accepted in international practice".

The research findings carried out within this article may contribute to the implementation of the principles, norms and standards of international customs law by Ukraine, and may be used to amend the Customs Code of Ukraine in power.

\section{References:}

1. Baimuratov M. O. (2006). Munitsypalne pravo Ukrainy: pidruchnyk. M. O. Baimuratov ta in. : za red. V. F. Pohorilka, O. F. Frytskoho. Kyiv : Yurinkom Inter, 443.

2. Chentsov V. V. (2015). Mizhnarodni standarty modernizatsii mytnykh administratsii. Derzhavne upravlinnia ta mistseve samovriaduvannia, Vyp. 4 (27), 219-229.

3. Chorna O. V. (2013). Harmonizatsiia mytnoho zakonodavstva Ukrainy vidpovidno do mizhnarodnykh vymoh ta standartiv. Naukovyi visnyk Mizhnarodnoho humanitarnoho universytetu. S. : Yurysprudentsiia, № 6-3. T. 1, 113-115.

4. Chorna O. V. (2015). Harmonizatsiia mytnoho zakonodavstva Ukrainy do vymoh mizhnarodnykh standartiv: avtoref. dys. kand. yuryd. nauk: 12.00.07. Zaporizhzhia, 23.

5. Customs Blueprints - path ways to modern customs (2015). Luxembourg : Publications Office of the European Union, 140.

6. Customs blueprints: pathways to better Customs (2015). Retrieved from:https://ec.europa.eu/ taxation_customs/eu-training/customs-blueprints-pathways-better-customs_en

7. Denysenko S. I. (2015). Mizhnarodno-pravovi standarty sproshchennia ta harmonizatsii mytnykh protsedur u sferi mizhnarodnoi torhivli: dys. ... kand. yuryd. nauk: 12.00.11. Odesa, 81 .

8. Halipov S. V. (2011). Problemysootvetstvijazakonodatel'stvaRossijskojFederacii o tamo\#ennomdeleme\#dunarodnymstandartam $\mathrm{v}$ sferetamo\#ennogoregulirovanija: avtoref. dis. kand. jurid. nauk: 12.00.10. Moskva, 24. 
9. Internationalconvention on the simplificationand harmonization of customs procedures(2008). Retrieved from: http:/www.wcoomd.org/en/topics/facilitation/instrument-and-tools/conventions/ pf_revised_kyoto_conv/kyoto_new/preamble.aspx\#ar1

10. Kormych B. A. (2017).ProCustomsBlueprints, aboshchonetak z mytnoiureformoiu.Obozrevatel.ua. Retrievedfrom: https://www.obozrevatel.com/my/life/40127-pro-customs-blueprints-aboscho-ne-tak-z-mitnoyu-reformoyu.htm

11. Kyivets O. V. (2010). Suchasne mizhnarodne pravo : problemy efektyvnosti systemy cherez pryzmu dzherel mizhnarodnoho prava. Pravo i bezpeka, № 2 (34), 15-19.

12. Kyivets O. V. (2012). Yevropeiski pravovi standarty yak mizhnarodno-pravova katehoriia. Yevropeiskistudii i pravo (elektronne naukove vydannia), № 1. Retrieved from: http://eurolaw.org. ua/11-ukrainian-journal-of-european-studies/1-5-2012/44-2011-12-29-14-\# ftnref3.

13. Makarenko V. A. (Ed.) (2002). Standart, mezhdunarodnyj. Slovar'sovremennyhponjatij i terminov. 4-e izd., dorab. i dop. Moskva, 411, 246.

14. Moroz S. P., Kravchuk M. O. (2017). Standart yak skladova pravovoi systemy. Pravova pozytsiia, № 1 (18), 31-34.

15. Mytnyi kodeks Ukrainy (2012) : Zakon Ukrainy vid 13.03.2012 r. № 4495-VI. Vidomosti Verkhovnoi Rady Ukrainy,№ 44-45, № 46-47, № 48. St. 552.

16. Perepolkin S. M. (2007). Mizhnarodne mytne spivrobitnytstvo: Ramkovi standarty Vsesvitnoimy tnoiorhanizatsii. Mytna sprava, № 1 (49), 6-11.

17. Perepolkin S. M. (2009). Mizhnarodno-pravovi aspekty mytnoho spivrobitnytstva yevropeiskykh derzhav: dys. ... kand. yuryd. nauk : 12.00.11. Kharkiv, 206.

18. Perepolkin S. M. (2017). Pryntsypy mizhnarodnoho mytnoho prava yak katehoriia mizhnarodnoho prava. Pravova pozytsiia, № 1 (18), 53-62.

19. Predstavnyky DFS vzialy uchast u seminari shchodo zastosuvannia mytnykh standartiv YeS Customs Blueprints(2017). Retrieved from: http://blind.sfs.gov.ua/media-tsentr/novini/284669.html.

20. Pro skhvalennia Kontseptsii zaluchennia kompanii (radnykiv) do reformuvannia mytnyts Derzhavnoi fiskalnoi sluzhby (2016) : Rozporiadzhennia Kabinetu Ministriv Ukrainy vid 11.02.2016 r. № 267-r. Ofitsiinyi visnyk Ukrainy, № 30. St. 1213.

21. Pro standartyzatsiiu (2014): Zakon Ukrainy vid 05.06.2014 r. № 1315-VII. Vidomosti Verkhovnoi Rady Ukrainy, № 31. St. 1058.

22. Pustovit L. O. tain (uklad). (2000). Standart. Slovnyk inshomovnykh sliv : 23000 sliv ta terminolohichnykh slovospoluchen. Kyiv, 856.

23. SAFE Framework of Standards to Secure and Facilitate Global Trade(2015). Brussels, World Customs Organization, 73.

24. Sandrovskij K. K. (2001). Me\#dunarodnoe tamo\#ennoe pravo: u4ebnik. 2-e izd., ispr. Kiev : Znannja, KOO,207.

25. Shemshuchenko Yu. S. (holovaredkol.) ta in. (2003). Standart, standarty mizhnarodni. Yurydychna entsyklopediia. Kyiv, T. 5, 614, 615.

26. Shulha M. H. (2014). Mytne zakonodavstvo Ukrainy i mizhnarodni mytni standarty. Visnyk Natsionalnoho universytetu «Iurydychna akademiia Ukrainy imeni Yaroslava Mudroho», № 4 (19), 220-232.

27. Uhoda pro Asotsiatsiiu mizh Ukrainoiu, z odniiei storony, ta Yevropeiskym Soiuzom, Yevropeiskym spivtovarystvom $\mathrm{z}$ atomnoi enerhii i yikhnimy derzhavamy-chlenamy, $\mathrm{z}$ inshoi storony(2014) :Mizhnarodnyi dohovir vid 27.06.2014. Ofitsiinyi visnyk Ukrainy, № 75. T. 1. St. 2125.

28. Uriad skhvalyv Kontseptsiiu reformuvannia DFS (2017). Retrieved from: https://www.kmu. gov.ua/ua/news/249858653. 


\title{
ПЛЮРАЛІЗМ РОЗУМІННЯ СТАНДАРТІВ МІЖНАРОДНОГО МИТНОГО ПРАВА
}

\section{Сергій ПЕРЕПЬОЛКІН,}

Дніпропетровський державний університет внутрішніх справ, Украӥна psm-13@ukr.net

\section{Тетяна СИРОїД,}

Харківський національний університет імені В. Н. Каразіна, Україна syroid02@gmail.com

\begin{abstract}
Ретельного опрачювання структури та змісту потребує низка багатосторонніх міжнародних митних договорів, двосторонніх договорів України, актів Всесвітньої митної організації, інструментів Свропейського Союзу, нормативно-правових актів Украӥни та наукової літератури. Авторами проведено дослідження стандартів міжнародного митного права, яке трунтувалося на таких теоретичних положеннях: стандарти є самостійною категорією міжнародного митного права та відрізняються від його принципів і норм; у правовому регулюванні митних відносин стандартам міжнародного митного права відводиться допоміжна роль, бо на відміну від принципів і норм міжнародного митного права вони не призначені для здійснення самостійного регулювання митних відносин;стандарти міжнародного митного права є похідними від його принщипів та норм.

Поняття «стандарти міжнародного митного права» пропонується визначити як розроблені 3 метою сприяння реалізащії принципів та норм міжнародного митного права технічні специфікації, типові форми, зразки, еталони, моделі, методичні рекомендації щуодо провадження певного виду діяльності або досягнення очікуваних результатів, втілення приписів яких у практичну діяльність митних адміністрацій здійснюється суб'єктами міжнародного митного права з урахуванням індивідуальних потреб та можливостей,на умовах та у порядку, визначених міжнародно-правовими актами, за допомогою яких їх було прийнято.

Також через призму стандартів міжнародного митного права проведено аналіз Митного кодексу України і запропоновано рекомендації по його удосконаленню. Результати проведеного в межах иієї статті дослідження можуть сприяти здійсненню реалізації Украӥною принципів, норм і стандартів міжнародного митного права, а також бути використані для внесення змін до чинного Митного кодексу Украӥни.
\end{abstract}

Ключові слова: міжнародне митне право, стандарти, принципи, норми, міжнародні договори, Митний кодекс України. 